\title{
Preliminary sanitary analysis of supply and exhaust air of ventilation units working at special rooms
}

\author{
Sylwia Szczęśniak ${ }^{1,{ }^{*}}$, Agnieszka Trusz-Zdybek ${ }^{1}$, and Katarzyna Piekarska ${ }^{1}$ \\ ${ }^{1}$ Wydział Inżynierii Środowiska, Politechnika Wrocławska, Wyb. Wyspiańskiego 27, 50-370 \\ Wrocław, Poland
}

\begin{abstract}
This article is an attempt to estimate concentration of bacteria and fungi in characteristic places in two air handling units. The research was conducted with the units equipped with heat recovery exchanger and recirculation of exhaust air. Additionally, microbiological analysis was done for indoor and fresh air. We performed measurements regarding supply and exhaust air volume. This means that the air velocity inside ventilator chamber was known. The mean concentration of bacteria and fungi was specified for air filters on the supply and exhaust side. The efficiency of air filters was verified by the concertation of bacteria and fungi in fan chamber. This article confirms that bacteria content in supply air is always lower than in exhaust air despite air recirculation. In this work we proved that the position of Petrie plate is essential for bacteria and fungi measurement.
\end{abstract}

\section{Introduction}

Actually in Poland, there aren't any of guidelines of concentration limits of bacteria, fungi etc. for public utility buildings. The terms are set only for clean rooms. It is obvious that all ventilation and air-conditioning systems are the base of growing and hibernation of microorganisms. Source of primary pollution in HVAC systems is ambient air. Ambient air is vital for keeping proper hygienic conditions and is always processed in Air Handling Units before supply to the ventilated room. Secondary source of pollution as comes to bacteria and fungi present in ventilation systems are people and animals. Furthermore humidity condensing from ambient and internal air can help in growth of microorganisms. Main factors having influence on and types of microbiota are: emission source type, microbes emission size, distance from emission source, microbes survivability, weather conditions (temperature, wind speed, humidity, precipitation, natural light, UV level) and season [1-3].

\footnotetext{
*Corresponding author: sylwia.szczesniak@pwr.edu.pl, agnieszka.trusz-zdybek@pwr.edu.pl
} 


\section{Research facility}

To establish the quantities of germs and fungi we've investigated two ventilation systems serving two non typical room in public buildings. Pollution sources were people and animals. There are water containers in the rooms with possibility of evaporation (depending on current heat/humidity balance). First investigated system (called System A) is a typical ventilation system without cooling capability, equipped with air recirculation and heat recovery. Second investigated system (called System B) is equipped with cooling module, air recirculation and heat recovery.

\subsection{Ventilation system „A"}

Figure 1 presents scheme of system A. Dashed line shows air flow direction on supply and exhaust side. Air velocity in supply air fan module was $w^{A}{ }_{s}=1,42 \mathrm{~m} / \mathrm{s}$ and in exhaust fan module $w_{e}^{A}=2,16 \mathrm{~m} / \mathrm{s}$.

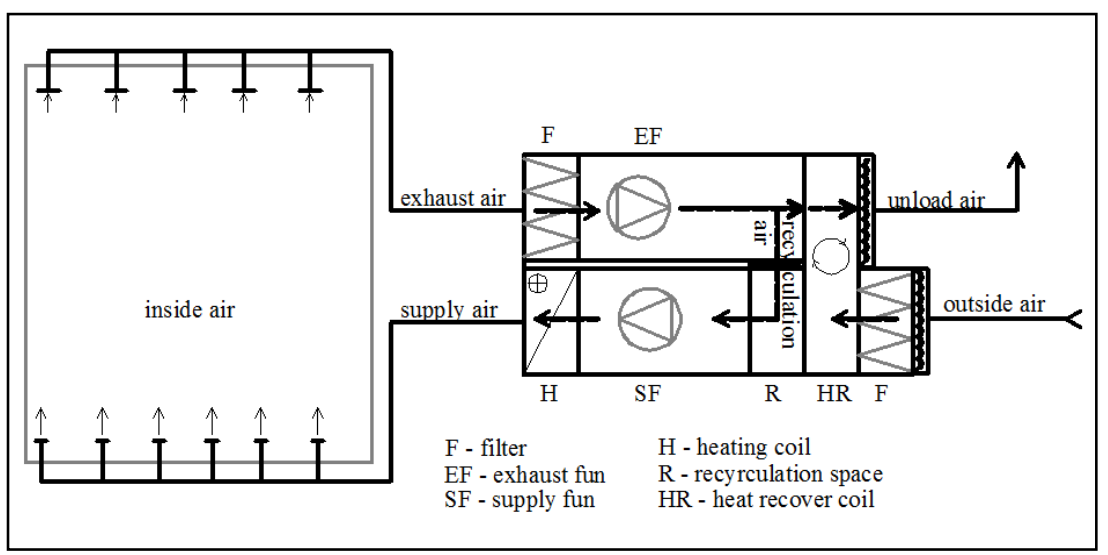

Fig. 1. Scheme of system A including air flow directions.

System A is used during autumn, winter and spring. System is not operating during summertime. During this period, room is ventilated naturally using opening roof. System uses air recirculation and heat recovery. Ambient air share in entire air volume equals $38 \%$ and is constant during work of the system. Air recirculation results in cost savings due to reduced heating requirements.

\subsection{Ventilation system „B”}

Figure 2. presents system B. Dashed line shows air flow directions on supply and exhaust side. Air velocity in supply fan module was $w^{B}{ }_{s}=3,59 \mathrm{~m} / \mathrm{s}$, and in exhaust fan module $w^{B}{ }_{e}$ $=3,18 \mathrm{~m} / \mathrm{s}$. 


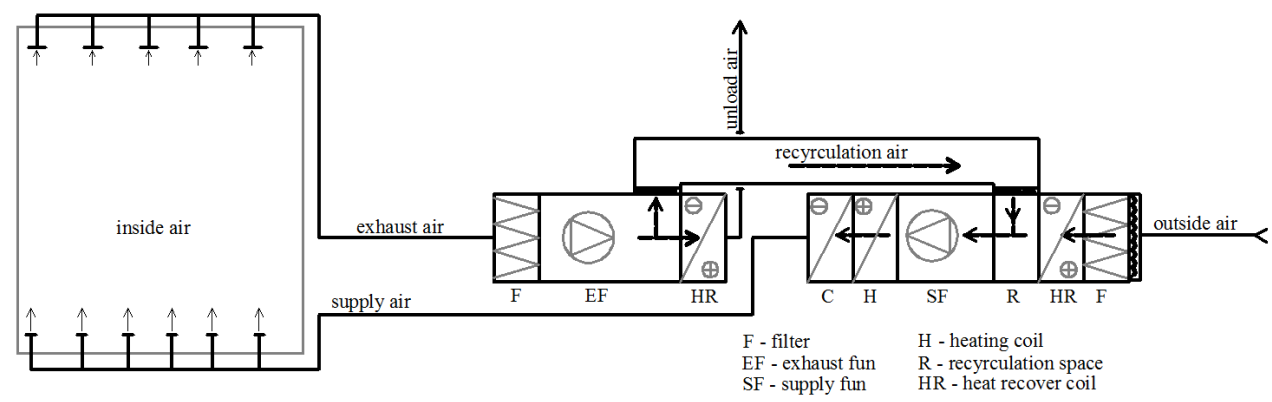

Fig. 2. Scheme of system A including air flow directions.

Ventilation system B is all year operating. This system is also equipped with heat recovery system and air recirculation. Ambient air share in total air volume equals $39 \%$ and is constant across the whole year.

\section{Description of the methods used in research}

Sanitary analysis was made twice - during operation and shutdown of the system in autumn and early spring. Differences were based on air filters contamination and weather conditions. To establish general germs and fungi quantities, measurements were done in supply and exhaust fan modules. Due to the difference between ambient air conditions and air pushed through fan sections, Petri plates were located in three positions: 1 - plate based horizontally on the level, 2 - plate based vertically with counter flow ground location, 3 - plate based vertically with the ground along the airflow. Plates configuration is presented in Fig. 3. Exhaust fan module was chosen for detailed measurements of Petri plates configuration and it's influence to the final results. Exhaust fan module removes room air containing primary and secondary pollutions.

a)

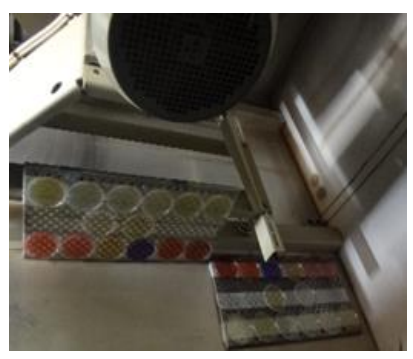

b)

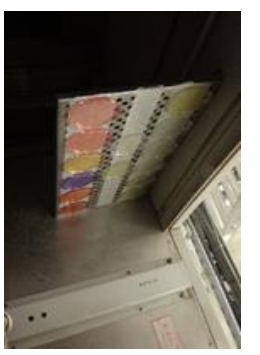

c)

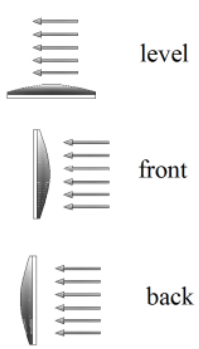

Fig. 3. a, b - Pictures presenting measurement plates in exhaust fan module.

Fig. 3. $\mathrm{c}$ - Petri plates configuration against air flow.

For assessment of air microbiological contamination we've chosen general quantity of mesophilic germs cultured on Trypticasein Soy LAB-AGAR ${ }^{\mathrm{TM}}$ substrate provided by Biocorp. Air tests to provide assessment of microbiological pollution due to many dangers for health or even life were done using three different substrates dedicated for fungi cultivation provided by Biocorp Czapek-Dox, Sabouraud Dextrose LAB-AGAR ${ }^{\mathrm{TM}}$, Malt Extract LAB-AGAR ${ }^{\mathrm{TM}}$. Bacteriological contamination of air filters and heat exchangers 
surface was done by measurement of general quantity of psychrophilic and mesophilic germs on substrate Trypticasein Soy LAB-AGAR ${ }^{\mathrm{TM}}$ by Biocorp.

\subsection{Pollution measurements - Assessment of microbiological purity of the air, air filters surface and heat exchangers}

Microbiological purity was carried out using sedimentation method (Koch method). This method is based on gravity sedimentation of microorganisms on specially prepared plates. Sanitary analysis of the air filters was done using swabs.

Open plates were left for sedimentation for the period of 15 minutes. After this time, plates were transported to the lab for incubation. Swabs were done on the surface of $25 \mathrm{~cm}^{2}$ using sterile swab stick. After that operation, stick was placed into solution of $0,9 \% \mathrm{NaCl}$ $\left(4.5 \mathrm{~cm}^{3}\right)$. Vortex mixer was used for surface cultures.

Apart from drawing method, samples were incubated in optimal conditions for microorganisms grow: mesophilic bacteria in $37^{\circ} \mathrm{C}$ for 48 hours, psychrophilic bacteria in $22{ }^{\circ} \mathrm{C}$ for 72 hours, fungi in $26^{\circ} \mathrm{C}$ for 5 days.

For sedimentation method Omelinski formula was used to calculate general quantity of microorganisms in $1 \mathrm{~m}^{3}$ of air (assuming that number of sedimenting microorganisms on $100 \mathrm{~cm}^{2}$ plate within 5 minutes equals the quantity of microorganisms in $10 \mathrm{dm}^{3}$ of air).

In swab method used for air filters examination, we've counted adult colonies and calculated CFU number for the surface of $25 \mathrm{~cm}^{2}$, taking into account the volume of solution used in vortex mixing operation $\left(4.5 \mathrm{~cm}^{3}\right)$ and culture volume on the surface $(4.5$ $\left.\mathrm{cm}^{3}\right)$.

\section{Results and Discussion}

\subsection{Pollution measurements using sedimentation method in supply and exhaust fans modules.}

Figures $4 \div 7$ present measurements results of general quantity of mesophilic bacteria and fungi in supply and exhaust fan modules during their operation and shutdown.

Highest TNB (Total Number of Bacteria) value for system A (Fig. 3) was measured during exhaust fan shutdown in October 2016 and it equaled $12575 \mathrm{CFU} / \mathrm{m}^{3}$, lowest value (393 $\mathrm{CFU} / \mathrm{m}^{3}$ ) was noticed in exhaust fan module in March 2017. During fan operation, highest TNB value $\left(19020 \mathrm{CFU} / \mathrm{m}^{3}\right)$ was noticed in October 2016 in ,back" configuration of the measurement plates. Lowest TNB value $\left(2778 \mathrm{CFU} / \mathrm{m}^{3}\right)$ was noticed with standard „level” configuration of the plates ,level”.

For system B (Fig. 5) lowest, fan shutdown TNB value was measured for supply fan in March 2017 and it was $236 \mathrm{CFU} / \mathrm{m}^{3}$, highest value $\left(1729 \mathrm{CFU} / \mathrm{m}^{3}\right)$ was measured in exhaust fan module at the same time. During fan operation, lowest and highest values were measured at exhaust fan. Highest value $\left(14574 \mathrm{CFU} / \mathrm{m}^{3}\right)$ was measured with „front” plate configuration in October 2016. Lowest value $\left(629 \mathrm{CFU} / \mathrm{m}^{3}\right)$ was observed in March $2017 \mathrm{r}$. for standard plate configuration.

In all cases, general quantity of mesophilic bacteria, calculated on a basis of highest indicated value (independent from plates configuration) is higher for measurements taken during operation of the fans (Fig.4 and 5) and is between $629 \mathrm{CFU} / \mathrm{m}^{3}$ (for exhaust fan and standard plates configuration) and $14574 \mathrm{CFU} / \mathrm{m}^{3}$ (for exhaust fan and „front” plate configuration. The only discrepancy in measurement results was noticed in October 2016. During fan shutdown results were close to highest TNB value for operating fan with „back” plates configuration. (Fig. 4). Highest values for operating fan were not noticed for standard 
(level) Petri plates configuration. In system A (Fig. 4) highest values $\left(19020 \mathrm{CFU} / \mathrm{m}^{3}\right)$ were noticed in „back” configuration of the plates. In system B (Fig. 5) highest quantities (14574 $\mathrm{CFU} / \mathrm{m}^{3}$ ) were observed in front configuration of the plates.

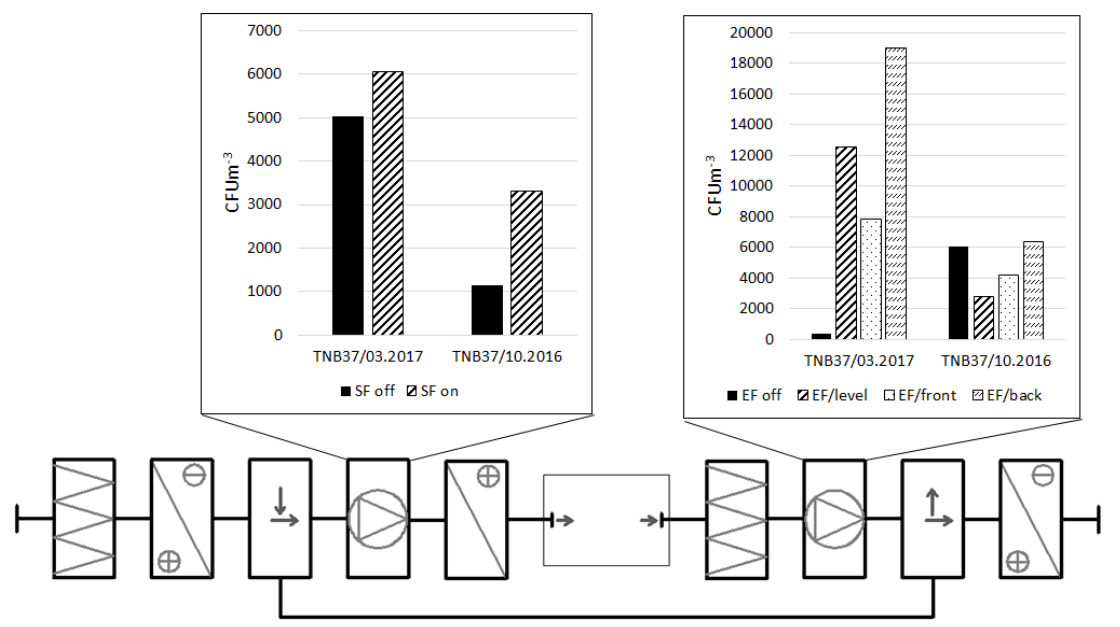

Fig. 4. Mesophilic bacteria measured in supply and exhaust fan modules for system A.

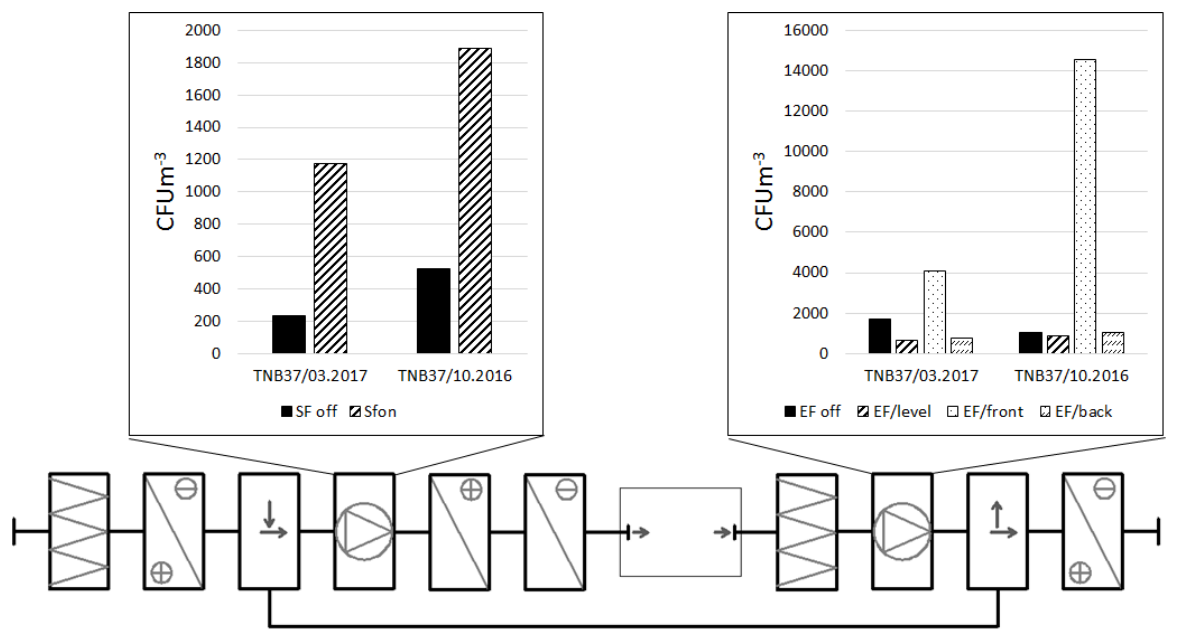

Fig. 5. Mesophilic bacteria measured in supply and exhaust fan modules for system B. 


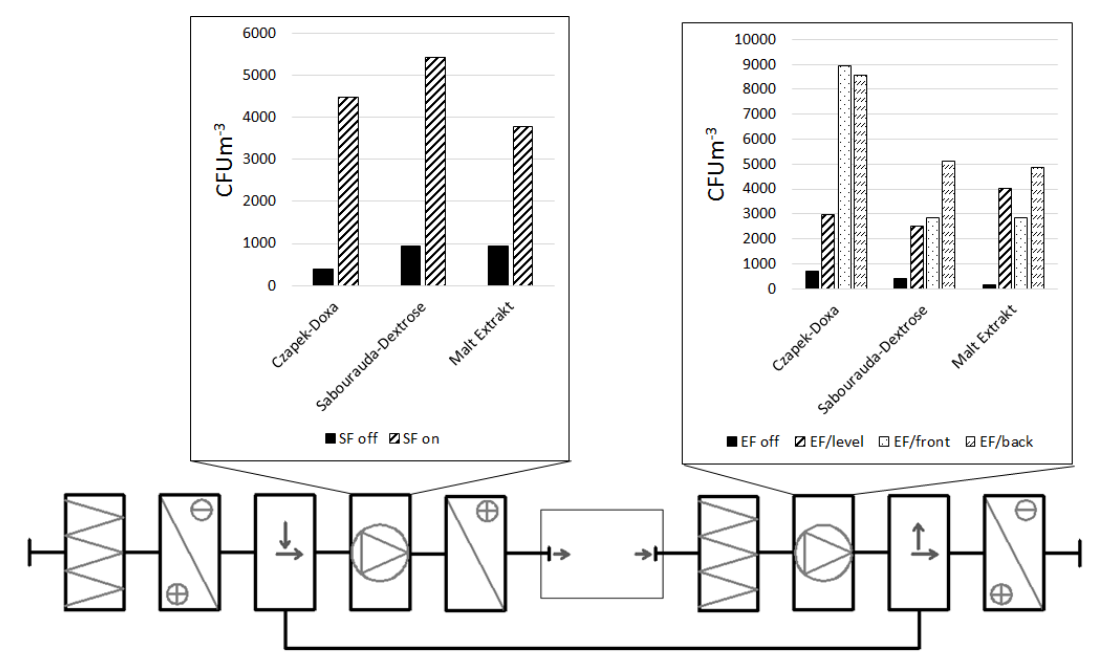

Fig. 6. General quantity of fungi measured in supply and exhaust fan modules in system A.

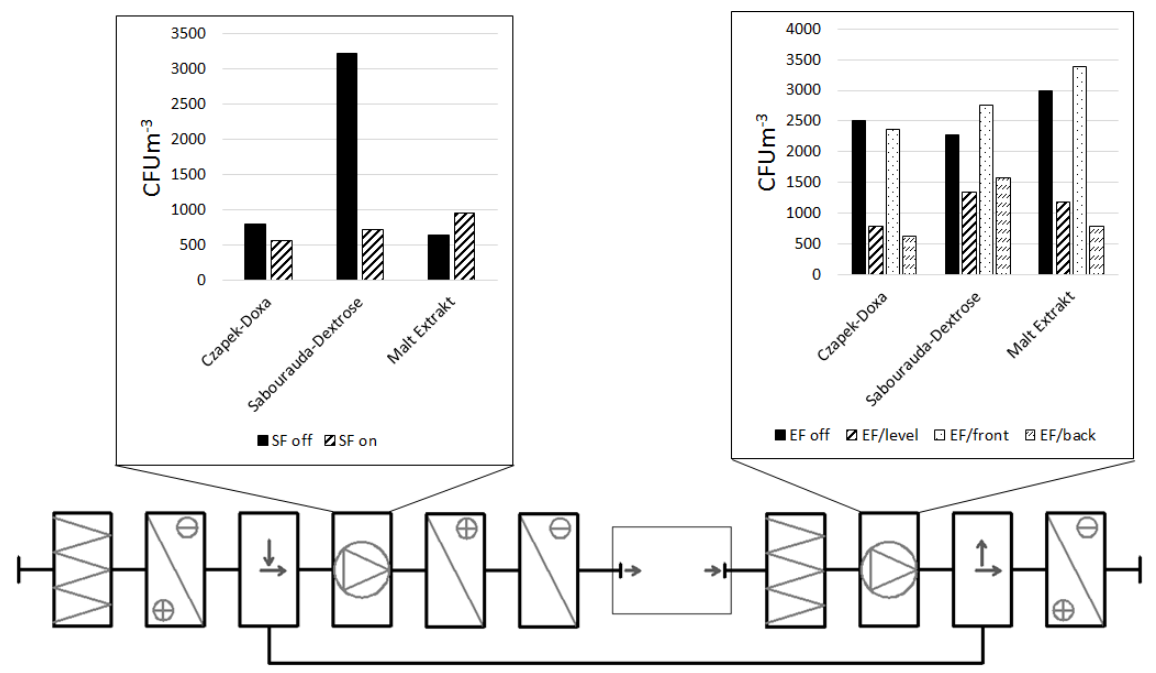

Fig. 7. General quantity of fungi measured in supply and exhaust fan modules in system B.

Data presented above (Fig. 6 and 7) suggest that general fungi quantity may not depend on operation/shutdown of the fan. Only in supply fan module TNF (Total Number of Fungi) values were lower during shutdown of the fan (independently from used substrate). In system A (the same like for mesophilic bacteria) higher values were noticed for operating fan. Highest value $\left(8960 \mathrm{CFU} / \mathrm{m}^{3}\right)$ was measured for "front” plates configuration , lowest value $\left(2515 \mathrm{CFU} / \mathrm{m}^{3}\right)$-for standard plates configuration Opposite results were measured for system B. Highest quantities in this case were observed for operating exhaust fan $\left(3380 \mathrm{CFU} / \mathrm{m}^{3}\right)$ with substrate Malt-Extrakt an ,front" plates configuration. Lowest results $\left(550 \mathrm{CFU} / \mathrm{m}^{3}\right)$ were observed with operating supply fan and Czapek-Doxa substrate. What's important, that supply fans were examined only with standard plates configuration. We have to take into account that standard (,level”) configuration of Petri plates didn't bring highest results of mesophilic bacteria. In this case we can conclude that other plates configuration could result in higher measurements than values taken during 
shutdown of the fan. In system A highest values $\left(8960 \mathrm{CFU} / \mathrm{m}^{3}\right)$ were achieved in „front” plate configuration and Czapek-Doxa substrate. For two other substrates higher values were measured for „back” plate configuration. In system B highest values were measured for „front” plates configuration $380 \mathrm{CFU} / \mathrm{m}^{3}$. At this stage of research we couldn't find any correlation between used substrate and maximum/minimum TNF value. In supply parts (for both A and B systems) (Fig. 6 and 7) highest TNF values were observed for substrate Sabourauda Dextrose. On the other hand, for exhaust fan in system A, highest TNF values were observed on Czapek-Doxa substrate $\left(8960 \mathrm{CFU} / \mathrm{m}^{3}\right)$ but only in ,front” and „back” configuration. In system B highest TNF values were noticed with substrate Malt Extrakt but only in ,front” plates configuration.

\subsection{Pollution measurements carried out on air filters and heat exchangers.}

Fig.8. and Fig.9. present measurements results of general quantities of bacteria taken from air filters and heat recovery heat exchangers in system A and B. Below the results we present the scheme of the systems and location of measurement points. Axis $\mathrm{Y}$ is logarithmic.

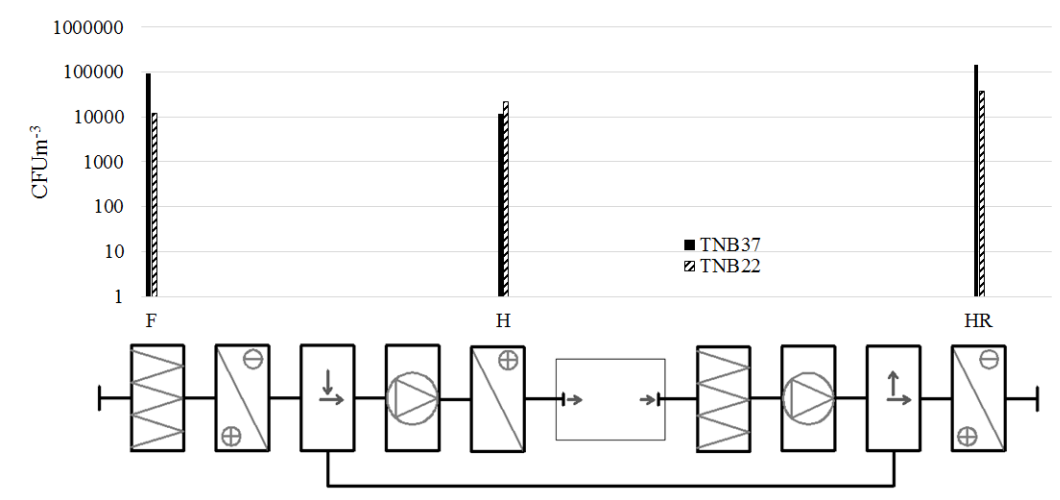

Fig. 8. Spores quantity measured in supply and exhaust fan modules in system A.

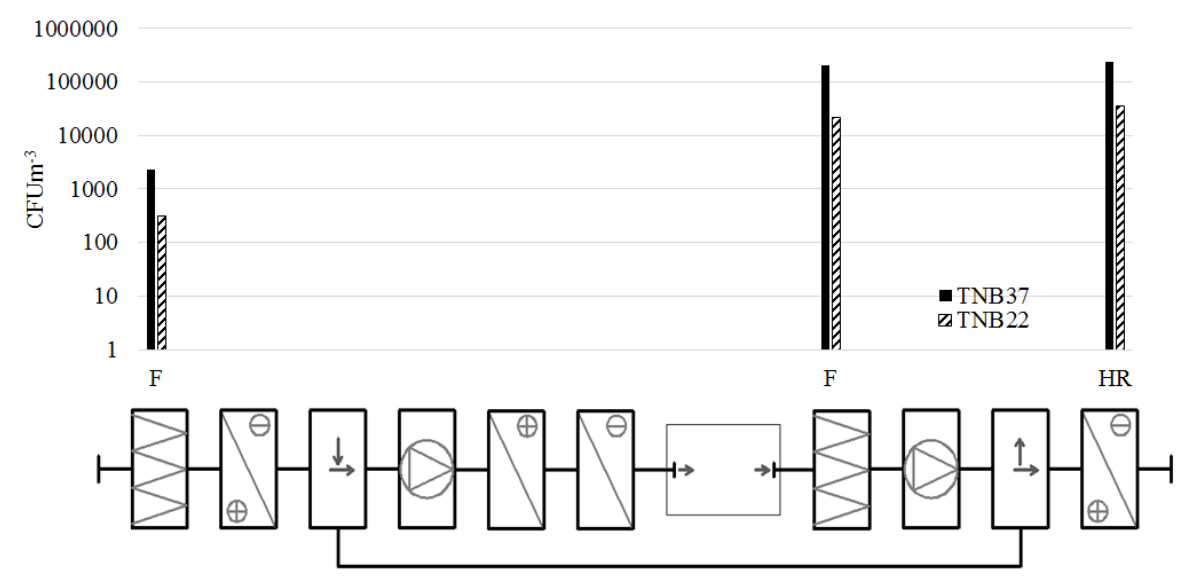

Fig. 9. Spores quantity measured in supply and exhaust fan modules in system B.

TNB value of mesophilic bacteria was higher (independently from examined option) except one case (air heater) than TNB of psychrophilic bacteria. In system A (Fig.8) highest 
TNB value of mesophylic bacteria $\left(142000 \mathrm{CFU} / \mathrm{m}^{3}\right)$ was observed on heat exchanger based in exhaust air unit. Lowest value was measured for ambient air $118000 \mathrm{CFU} / \mathrm{m}^{3}$. In system B (Fig.9) highest value $\left(233000 \mathrm{CFU} / \mathrm{m}^{3}\right)$ was notice on heat recovery coil , lowest $2300 \mathrm{CFU} / \mathrm{m}^{3}$ ) for ambient air filter. Measurements made on a basis swab samples from air filters and heat exchangers (Fig. 8 i 9) indicate that general quantity of mesophilic bacteria in both systems is higher on exhaust (dirty) side of the systems. This conclusion agrees with general rule of sanitary role of ventilation systems. We have to bear in mind that both systems use air recirculation so they partly re-use ,dirty” air. Important thing is that in system A (where it was possible to examine air heater) general quantity of mesophilic and psychrophilic bacteria was higher on the air filter than on air heater. In some sense this proves efficiency of the initial air filter which role is to clean the air from bigger dirt and dust particles. Heater wall temperature may also influence the quantity of bacteria.

\section{Conclusions}

1. General quantity of bacteria and fungi is always lower in air supply part, despite air recirculation.

2. Standard plates configuration (level) was never resulting in highest bacteria quantities.

3. For air velocity of $w=2,16 \mathrm{~m} / \mathrm{s}$ maximum general quantity was measured for „back” plates configuration. For air velocity of $w=3,18 \mathrm{~m} / \mathrm{s}-$,,front" configuration was resulting in highest values. This leads to a conclusion that air velocity and plates configuration may influence the sanitary assessment of ventilating air but this conclusion should be confirmed in further research activities that will be carries on specially prepared research station.

In most cases, maximum pollution values were observed during operation of the fans. During shutdowns, pollution quantities were lower than maximum. This relationship is not obvious for air supply fan, where only standard plates configuration (level) was possible to apply. In this case we have to remember that higher values were achieved for different plates configuration.

Initially we have to confirm that pollution values were always higher during operation of the fans.

\section{References}

1. A. Flannigan, Brian, Samson., A. Robert, Miller, J.David, Microorganisms in Home and Indoor Work Environments (CRCnetBASE,2011).

2. A.A. Abdel Hameed, M.I Khoder, Y.H. Ibrahim, Y.Saeed, M.E Osman, S.Ghanem, , SCI TOTAL ENVIRON, 414, 696 (2012).

3. A. Kiliszczyk, B.Podlaska, K.Sadowiec, B. Zielińska-Polit, M. Rychtel, S. Russel, Water-environment-rural areas, T13, 79 (IT-P w Falentach, 2013).

4. K. Bródka, M. Sowiak, A. Kozajda, M. Cyprowski, I. Szadkowska-Stańczyk, MED PR, 63(3), 303 (2012).

5. H. Awbi, Ventilation of building, (London and New York: Spon Press, 2003).

6. A. Pełech, Wentylacja i Klimatyzacja. Podstawy, (OWPW , 2009).

7. S. Przydróżny, Wentylacja, (WPW, 1991). 